\title{
Vibrio diseases of marine fish populations
}

\author{
R. R. Colwell \& D. J. Grimes \\ Department of Microbiology, University of Maryland; College Park, MD 20742 USA
}

\begin{abstract}
Several Vibrio spp, cause disease in marine fish populations, both wild and cultured. The most common disease, vibriosis, is caused by $V$. anguillarum. However, increase in the intensity of mariculture, combined with continuing improvements in bacterial systematics, expands the list of Vibrio spp. that cause fish disease. The bacterial pathogens, species of fish affected, virulence mechanisms, and disease treatment and prevention are included as topics of emphasis in this review.
\end{abstract}

\section{INTRODUCTION}

It is most appropriate that the introductory paper at this Symposium on Diseases of Marine Organisms should be about vibrios. The disease syndrome termed vibriosis was one of the first diseases of marine fish to be described (Sindermann, 1970; Horne, 1982). Called "red sore", "red pest", "red spot" and "red disease" because of characteristic hemorrhagic skin lesions, this disease was recognized and described as early as 1718 in Italy, with numerous epizootics being documented throughout the 19th century (Crosa et al., 1977; Sindermann, 1970). Today, while "red sore" is, without doubt, the best understood of the marine bacterial fish diseases, new diseases have been added to the list of those caused by Vibrio spp.

The more recently published work describing Vibrio disease, primarily that appearing in the literature since 1977, will be the focus of this paper. Bacterial pathogens, the species of fish affected, virulence mechanisms, and disease treatment and prevention are included as topics of emphasis. For discussions of earlier work, the reader is referred to Sindermann (1970) and Roberts (1982).

\section{VIBRIOS AS BACTERIA PATHOGENIC FOR FISH}

All members of the genus Vibrio are Gram-negative rods ranging in size and morphology from coccobacilli to definite rod-shape cells that may exhibit some degree of curvature, i.e., vibrioid. Under conditions of nutrient depletion or in the natural environment, including estuaries and the ocean, where oligotrophic conditions occur, vibrios will occur as small coccoid forms, representing a strategy for survival (Singleton et al, 1982 ; Xu et al., 1982; Novitsky \& Morita, 1976). Vibrio spp. are motile by means of a sheathed, polar flagellum, one or more at one pole of the cell. Some species also form non-sheathed lateral flagella, when grown on solid media. Lateral flagella play a role in attachment to surfaces and also appear to be involved in swarming (Belas \& Colwell, $1982 a ; 1982 b)$. 
Biochemical features of the genus include fermentation of glucose, usually without the production of gas; sensitivity to $150 \mu \mathrm{g}$ vibriostat $0 / 129$ (2,4-diamino-6,7-diisopropylpteridine) per ml of medium; positive oxidase reaction, except for $V$. metschnikovii and $V$. gazogenes; and an absolute requirement for $\mathrm{NaCl}$ (West \& Colwell, 1984). The over-all DNA base composition, i.e., percent guanine plus cytosine, for the genus ranges from 38 to $51 \%$, with the type species, $V$. cholerae, having an average $\% \mathrm{G}+\mathrm{C}$ of 47 . Table 1 lists salient features of the genus, useful in identifying the fish pathogens.

Table 1. Characteristics useful in identifying those members of the genus Vibrio that have been shown to be pathogenic for fish*

\begin{tabular}{|c|c|c|c|c|c|c|c|c|c|}
\hline \multirow{3}{*}{ Characteristic } & \multirow{3}{*}{$\begin{array}{l}\text { algino- } \\
\text { lyticus }\end{array}$} & \multirow{3}{*}{$\begin{array}{l}\text { anguil- } \\
\text { larum }\end{array}$} & \multirow{3}{*}{$\begin{array}{l}\text { carcha- } \\
\text { riae }\end{array}$} & \multicolumn{2}{|c|}{ Vibrio } & \multirow{3}{*}{$\begin{array}{l}\text { orda } \\
\text { lii }\end{array}$} & \multirow{3}{*}{$\begin{array}{c}\text { para- } \\
\text { haemoly- } \\
\text { ticus }\end{array}$} & \multirow{2}{*}{\multicolumn{2}{|c|}{$\begin{array}{l}\text { vulni- } \\
\text { ficus }\end{array}$}} \\
\hline & & & & $\begin{array}{l}\text { cho- } \\
\text { lerae }\end{array}$ & $\begin{array}{l}\text { dam- } \\
\text { sela }\end{array}$ & & & & \\
\hline & & & & & & & & 1 & 2 \\
\hline \multicolumn{10}{|l|}{$0 / 129$} \\
\hline $10 \mu \mathrm{g}$ & $\mathrm{R}$ & $\mathrm{s}$ & $\mathbf{R}$ & $\mathbf{s}$ & $\mathrm{s}$ & $\mathrm{s}$ & $\mathbf{R}$ & $\mathrm{s}$ & $\mathrm{S}$ \\
\hline $150 \mu \mathrm{g}$ & $\mathrm{s}$ & $\mathrm{s}$ & S & s & S & $\mathrm{S}$ & $\mathrm{s}$ & $\mathrm{S}$ & $\mathrm{S}$ \\
\hline Swarming & + & - & + & - & - & - & $\mathrm{V}$ & - & - \\
\hline \multicolumn{10}{|l|}{ Amino acids** } \\
\hline arginine & - & + & - & - & + & - & - & - & - \\
\hline lysine & + & - & + & + & - & - & + & + & + \\
\hline ornithine & + & - & + & + & - & - & + & + & - \\
\hline \multicolumn{10}{|l|}{ Fermentation } \\
\hline glucose & A & A & A & A & AG & A & A & A & A \\
\hline lactose & - & - & - & - & - & - & - & A & A \\
\hline mannose & A & A & A & A & AG & - & A & A & A \\
\hline salicin & - & - & A & - & - & - & - & A & A \\
\hline sucrose & A & A & A & A & - & A & - & - & - \\
\hline Urease & - & - & + & - & + & - & $\mathrm{V}$ & $\mathrm{V}$ & - \\
\hline Indole & + & + & + & + & - & - & + & + & - \\
\hline Voges-Proskauer & + & + & - & + & + & - & - & - & - \\
\hline \multicolumn{10}{|l|}{ Growth at $\% \mathrm{NaCl}$} \\
\hline 0 & - & $\mathrm{V}$ & - & $\mathrm{V}$ & - & - & - & - & - \\
\hline 3 & + & + & + & + & + & + & + & + & + \\
\hline 6 & + & + & + & V & V & + & + & + & - \\
\hline 8 & + & V & + & - & - & - & + & - & - \\
\hline 10 & + & - & - & - & - & - & - & - & - \\
\hline Growth at $42^{\circ} \mathrm{C}$ & + & - & - & + & - & - & + & + & - \\
\hline $\begin{array}{r}+=90 \% \text { of a } \\
90 \% \text { of all stra } \\
\text { resistant, } \mathrm{S}=\mathrm{s} \\
\cdots \quad \text { arginine dihyd }\end{array}$ & $\begin{array}{l}\text { strains g } \\
\text { ns are ne } \\
\text { ensitive; } t \\
\text { olase, lysi }\end{array}$ & $\begin{array}{l}\text { ive a posi } \\
\text { jative, } V \\
\text { est proce } \\
\text { ne and or }\end{array}$ & $\begin{array}{l}\text { tive react } \\
=\text { variab } \\
\text { ures are } \\
\text { nithine d }\end{array}$ & $\begin{array}{l}n,(+) \\
\text { reactic } \\
\text { ven by } \\
\text { arboxy }\end{array}$ & $\begin{array}{l}\text { weak } \\
\text { s, A = } \\
\text { Nest \& } \\
\text { se }\end{array}$ & $\begin{array}{l}\text { d/or de } \\
\text { id, AG } \\
\text { lwell ( }\end{array}$ & $\begin{array}{l}\text { layed posit } \\
=\text { acid }+ \\
\text { 1984). }\end{array}$ & $\begin{array}{l}\text { ve, } \\
\text { gas, }\end{array}$ & R $=$ \\
\hline
\end{tabular}

The natural habitat of Vibrio spp. is estuarine and marine water and sediment. Vibrios often occur in association with invertebrate and vertebrate animal surfaces and internal organs (Huq et al., 1983; Grimes et al., 1984b). Stress can compromise the animal host, resulting in a commensal species switching to pathogenicity as the mode of interaction (Grimes et al., 1984c). 


\section{Vibrio alginolyticus}

Formerly classified as $V$, parahaemolyticus biotype $2, V$. alginolyticus often exhibits pronounced swarming on complex media, produces a positive Voges-Proskauer reaction, tolerates $10 \% \mathrm{NaCl}$, and grows at temperatures up to $42^{\circ} \mathrm{C}$. It ferments sucrose and decarboxylates lysine and ornithine (Table 1).

$V$. alginolyticus is frequently isolated from fin fish, shellfish, seawater, and sediment (Gjerde \& Boe, 1981; Joseph et al., 1982). It is not widely recognized as a fish pathogen, even though it has been associated with ulcer disease (Akazawa, 1968) and mortality of sea-bream (Colorni et al., 1981; Iwata et al., 1978) (see Table 2). Recently, Burke \&

Table 2. Vibrio species known to cause disease in marine fish

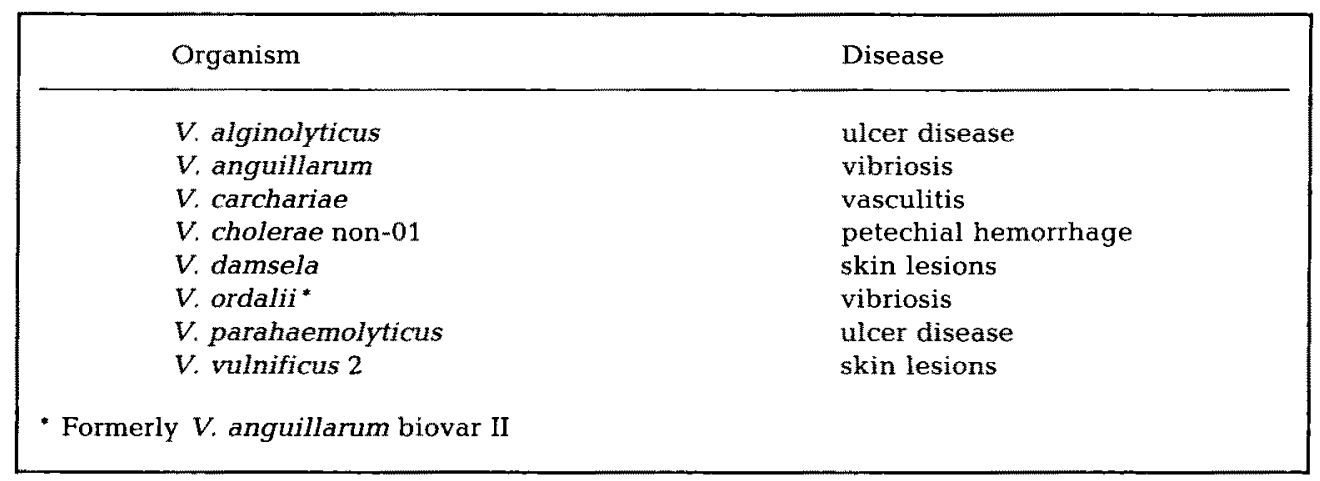

Rodgers (1981) found $V$, alginolyticus to be a secondary invader of "red spot", a disease caused by $V$. anguillarum. Gauthier \& Clement (1979) observed a streptomycin-resistant strain of $V$. alginolyticus to be present not only in sediment but also water, when the water temperature exceeded $16^{\circ} \mathrm{C}$. However, food chain transmission was not observed when reconstructed marine food chains were studied in the laboratory (Gauthier \& Clement, 1979).

It is well established that $V$. alginolyticus can colonize the human gut (Sakazaki et al., 1963). In fact, Hiratsuka et al. (1980) observed the cause of acute enterocolitis in a patient who consumed trout roe contaminated with the same bacteria to be $V$. alginolyticus. More frequently, $V$. alginolyticus is associated with skin infections (Blake et al., 1980), such as conjunctivitis and stump ulcer cases described by Schmidt et al. (1979). Even though Blake et al. (1980) reported that little work has been done on virulence mechanisms, it is probable, based on available evidence, that the collagenase and several extracellular proteases produced by $V$. alginolyticus (Long et al., 1981) participate in the invasion of fish and human skin.

\section{Vibrio anguillarum}

This vibrio, the first recognized to be a fish pathogen, includes strains capable of utilizing arginine and tolerant of $6 \% \mathrm{NaCl}_{\text {; }}$ some strains tolerate $8 \%$ salt and others are capable of growth in the presence of trace amounts of salt, i.e., they are reported to grow 
in $0 \%$ salt, but in fact, require the concentration of $\mathrm{NaCl}$ present in peptone used to prepare the medium (Singleton et al., 1982). $V$. anguillarum is sensitive to $10 \mu \mathrm{g} 0 / 129$, gives a positive Voges-Proskauer reaction and ferments sucrose (Table 1). Recently, strains referred to as $V$, anguillarum biovar II were described as a new species, $V$. ordalii sp. nov. (Schiewe et al., 1981) vide infra.

Vibriosis of $V$. anguillarum etiology has been described in over 42 species of fish, including ayu, eel, cod, pike, brown trout, flounder, striped bass and salmon. Vibriosis has been especially devastating to salmon reared in Pacific coastal waters (Crosa et al., 1977). Vibriosis is a typical Gram-negative septicemia, exhibiting extensive hemorrhaging and necrosis in the internal organs and musculature. It is a rapidly fulminating disease, affecting both cultured and wild marine fish. Gross clinical signs of the disease include hemorrhaging of the fins, eyes, and ventral surface.

It is interesting to note the progression of discovery of $V$. anguillarum throughout the world. It was first described in Europe, as the agent of "red spot" in eels (Bergman, 1909; Horne, 1982; Sindermann, 1970). Its recovery from diseased fish in North America did not occur until 1953 (Crosa et al., 1977), and Muroga et al. (1976) suggest that the first isolation of $V$. anguillarum in Japan in 1975 may have resulted from contaminated eels imported from France. Whether or not there was a true geographic spread (natural or anthropogenic) of $V$. anguillarum, or merely a circumstantial sequence of discovery is open to speculation.

Two of the more recent developments with regard to $V$. anguillarum are very exciting and should lead to effective control of this fish pathogen. Virulence factors, and their genetic control, are receiving much attention in several laboratories. Also promising are several approaches to vaccination being investigated.

An interesting phenomenon was recently reported for $V$. anguillarum isolates from ayu cultured in Japan. Muroga et al. (1979a) found that 27 of 52 isolates were not sensitive to vibriostatic agent $0 / 129$, previously thought to be a significant attribute of Vibrio spp. These isolates were obtained from ayu that had been raised in ponds that contained prophylactic trimethoprim-sulfadoxine (TS). Similar findings were reported by Aoki et al. (1981), after examination of 132 strains of $V$. anguillarum for resistance to $0 / 129$ and trimethoprim. Transferable $\mathrm{R}$ plasmids were suspected, but could not be demonstrated.

\section{Vibrio carchariae}

The original isolate of $V$. carchariae was obtained from a dead sandbar (brown) shark (Carcharhinus plumbeus) (Grimes et al., 1984a). Subsequently, it has been isolated from lemon sharks (Negaprion brevirostris) and from trematodes infesting the skin of lemon sharks (Grimes et al., 1984c). $V$. carchariae is a swarming vibrio that exhibits mixed flagellation. Morphologically, and in terms of several biochemical attributes, $V$. carchariae is practically indistinguishable from $V$. alginolyticus and the sucrose-positive, urease-positive strains of Vibrio parahaemolyticus. However, unlike these two vibrios, $V$. carchariae can not grow at $42^{\circ} \mathrm{C}$; other differences include growth in $10 \%$ $\mathrm{NaCl}$ and Voges-Proskauer (Table 1), as well as DNA homology.

$V$. carchariae is described in detail elsewhere in this Symposium volume (Grimes et al., $1984 \mathrm{~b}$ ). The host range of $V$. carchariae has not yet been thoroughly investigated, since the type strain was isolated only in 1982 . With regard to sharks, $V$. carchariae 
causes a vasculitis, especially in organs of the reticuloendothelial system. It also causes, or is frequently isolated from, dermal lesions and cysts in sharks. Recently, Grimes et al. (1984c) hypothesized that shark trematodes (Dermophthirius nigrellii) may serve as a vector for $V$. carchariae.

\section{Vibrio cholerae}

Serovars of $V$. cholerae, other than serovar 01, are occasionally isolated from fish. These $V$. cholerae serovars have been referred to as non-agglutinable (NAG) vibrios and as non-cholera vibrios (NCV), a practice that has created much confusion and is not acceptable nomenclature (West \& Colwell, 1984). The non-01 V. cholerae strains do not react with the 0 antiserum originally designated as 01 .

In a study of the Danube River, Strusiewicz et al. (1980) isolated $V$. cholerae non-01 from water, fish, and sewage outfalls. The highest incidence of positive samples occurred during September (the warmest month) and $81.9 \%$ of the isolates were enterotoxigenic, measured by rabbit ileal loop assay. Enterotoxigenic strains were recovered more frequently from fish than from water samples (Strusiewicz \& Serban, 1980). In a similar study, Szeness et al. (1979) isolated $V$. cholerae non-01 from fish, frogs, and birds. Neither of these studies, however, commented on the health status of the fish from which the $V$. cholerae isolates were obtained.

Muroga et al. (1979b) isolated a Vibrio sp. from diseased ayu and demonstrated that the isolate was the causative agent of an ayu epizootic. Briefly, the disease was characterized by petechiae on the body surface and by internal organ congestion. The isolates were morphologically and biochemically very similar to $V$. cholerae, but did not agglutinate in either Ogawa or Inaba antisera, i.e., they were non-01 serovar. Muroga et al. (1979b) also determined the \% G+C base ratio for their isolates (47 to $47.7 \%$ ), and demonstrated $86 \%$ DNA homology between their isolates and $V$. cholerae NIH35A3. There is little doubt that the cause of the ayu epizootic was the human pathogen, $V$. cholerae.

In a later study, Yamanoi et al. (1980) demonstrated that one of the ayu $V$. cholerae isolates (strain PS-7701) survived for 320 days at $25^{\circ} \mathrm{C}$ in freshwater, $0.85 \% \mathrm{NaCl}$ solution, Ringer solution, seawater, and in diluted seawater. They further noted that survival in water was greatly reduced at $2^{\circ} \mathrm{C}$, a finding similar to that of Singleton et al. (1982). Related to this observation was the fact that healthy ayu could not be reinfected with $V$. cholerae, when the ayu were held at $16^{\circ} \mathrm{C}$. However, when infected by the immersion method (ca. $1.26 \times 10^{4}$ cells $/ \mathrm{ml}$ ) and held at $21^{\circ} \mathrm{C}$ and $26^{\circ} \mathrm{C}$, most of the ayu died within 4 days post infection. The $V$. cholerae strain was also pathogenic for eels (Anguilla japonica) and for mice.

\section{Vibrio damsela}

First isolated from damselfish off the coast of southern California (Love et al., 1981), $V$. damsela is now known to infect humans (Love et al., 1981) and sharks (Grimes et al., $1984 a$ ). Distinguishing attributes of $V$. damsela include its ability to metabolize arginine and to produce gas during fermentation of glucose and other selected sugars (Table 1).

$V$. damsela causes characteristic skin ulcers in the blacksmith, a temperate-water damselfish (Chromis punctipinnis), and in garibaldi (Hypsypops rubicunda), and was 
thought by Love et al. (1981) to have a narrow host range. However, we isolated $V$. damsela, along with $V$. carchariae, from a dead sandbar shark (C. plumbeus), and subsequently demonstrated $V$. damsela to be virulent for the spiny dogfish shark (Squalus acanthias) (Grimes et al., 1984a). Although we have not been successful in producing disease in lemon sharks ( $N$. brevirostris) experimentally infected with $V$. damsela, $V$. damsela was cultured from the stomach of a wild lemon shark (Grimes et al., unpubl. data).

\section{Vibrio ordalii}

$V$. ordalii was recently proposed by Schiewe et al. (1981) to include all strains previously designated as $V$. anguillarum biovar II. It is differentiated from $V$, anguillarum by giving negative reactions for: Voges-Proskauer; arginine dihydrolase; citrate; starch; ONPG; lipase; growth at $37^{\circ} \mathrm{C}$; and acid from cellobiose, glycerol, sorbitol, and trehalose (Table 1). Detailed discussion of $V$. ordalii is provided in the recent review by Schiewe (1983).

$V$. ordalii causes vibriosis in salmonid fish in the Pacific Northwest and in Japan. This species appears to have a more host-dependent mode of existence than does $V$. anguillarum, because it is rarely isolated from water, sediment, or other abiotic marine samples; $V$. ordalii is recovered only from moribund fish (Schiewe, 1983). V. ordalii preferentially colonizes skeletal muscle, cardiac muscle, gills, and the gastrointestinal tract of salmonids, in contrast to $V$. anguillarum, which presents disseminated infections, with highest numbers in blood, loose connective tissue, kidney, spleen, gills, and in the posterior gastrointestinal tract. Several investigators have observed a marked leukopenia in moribund fish, suggesting the presence of a powerful leukocytolytic factor in $V$. ordalii (Schiewe, 1983).

\section{Vibrio parahaemolyticus}

First recognized as the etiologic agent of human seafood-borne disease in Japan in the $1950 \mathrm{~s}, V$. parahaemolyticus is the most thoroughly studied Vibrio sp., next to $V$. cholerae. Notable features of $V$. parahaemolyticus include swarming, growth at $42^{\circ} \mathrm{C}$, negative arginine reaction, and resistance to $10 \mu \mathrm{g}$ of $0 / 129 . \mathrm{V}$. parahaemolyticus is considered to be non-sucrose fermenting. However, sucrose positive variants do exist, and are usually overlooked during routine clinical isolation (West \& Colwell, 1984).

$V$, parahaemolyticus causes gastroenteritis in humans and has also been implicated in extraintestinal infections (Blake et al., 1980; Joseph et al., 1982). An enterotoxin appears to be involved, but has yet to be conclusively demonstrated (Joseph et al., 1982). $V$. parahaemolyticus was so named because of its ability to produce beta-hemolysis on high-salt blood agar, a reaction that has been designated the Kanagawa phenomenon. For reasons as yet unknown, only human clinical isolates seem to give a positive Kanagawa reaction; environmental isolates of $V$. parahaemolyticus, including fish isolates, are rarely Kanagawa positive (Joseph et al., 1982).

The role of $V$. parahaemolyticus in fish disease is more obscure, and fish may simply function as a passive carrier. Like $V$. alginolyticus, $V$. parahaemolyticus is frequently isolated from both healthy and diseased fish throughout the world (Lall et al., 1979; Lhuillier, 1977; Franca et al., 1980; Qadri \& Zuberi, 1977; Nair et al., 1980). Important 
habitats for $V$. parahaemolyticus include sediment and shellfish (both oysters and crustaceans), with movement into the water column occurring during warmer months (Kaneko \& Colwell, 1978; Joseph et al., 1982; Gjerde \& Boe, 1981; Natarajan et al., 1980). $V$. parahaemolyticus is occasionally isolated from skin ulcers of fish, but usually in association with other vibrios (Yasunaga \& Yamamoto, 1977). Kusuda et al. (1979) has isolated $V$. parahaemolyticus from vibriosis of red sea-bream cultured in Japan, and Gilmour (1977) recovered the species from fish farm tank water. Ortiz \& Decker (1976) detected anti- $V$. parahaemolyticus antibody in the sera of 13 of 26 flounder examined; Robohm et al. (1979), on the other hand, did not detect significant titers of anti- $V$. parahaemolyticus antibody in the fish they examined. The status of $V$.parahaemolyticus as a fish pathogen needs to be more completely documented.

\section{Vibrio vulnificus}

$V$. vulnificus is a lactose-fermenting vibrio that, in many respects resembles $V$. alginolyticus and $V$. parahaemolyticus (Table 1). Originally referred to as a lactosepositive vibrio, $V$. vulnificus is recognized as a highly virulent, opportunistic human pathogen with a low incidence of disease (Oliver et al., 1983; Joseph et al., 1982; Blake et al., 1980). Oliver et al. (1983) studied the distribution of sucrose-negative vibrios in seawater, sediment, plankton, and animal samples collected at 80 sites from Miami, Florida to Portland, Maine. They concluded that $V$. vulnificus was ubiquitous, both geographically and in terms of presence in a variety of environmental samples. However, absolute numbers of $V$. vulnificus were always found to be low, since Oliver et al. (1983) demonstrated that only 33 isolates $(0.83 \%)$ of 3,887 sucrose-negative vibrios examined fermented lactose.

Tison et al. (1982) reported on a new subgroup, biogroup 2, of $V$. vulnificus that is pathogenic for eels. Previously, the names $V$. anguillarum type $B$ and $V$, anguillicida had been used to describe these vibrios (Nishibuchi et al., 1979). Briefly, the eel disease caused by $V$. vulnificus biogroup 2 is a vibriosis characterized by a red patch or swollen lesion on the trunk or tail. In early stages of the disease, the skin and lateral musculature is primarily involved; advanced stages involve histopathological changes in the spleen, liver, kidney, heart, gills, and intestine (Miyazaki et al., 1977).

$V$. vulnificus biogroup 2 differs from $V$. vulnificus biogroup 1 in several characteristics (Table 1), and the two biogroups do not share common surface antigens (Tison et al., 1982). However, because of the strong reassociation ( $>90 \%$ ), under stringent conditions, of DNA from clinical $V$. vulnificus strains (i.e., biogroup 1) with DNA from eel isolates, Tison et al. (1982) proposed that the eel isolates, and strains phenotypically resembling the eel isolates, be classified as $V$. vulnificus biogroup 2 .

\section{Luminous Vibrio spp.}

Although not known to be pathogenic for fish, the luminous vibrios deserve brief mention. These interesting species are symbionts of fish, living in the luminous organ (Ruby et al., 1980; Yetinson \& Shilo, 1979; Hastings \& Nealson, 1977). The principal species are $V$. fischeri and $V$. harveyi, although occasional strains of $V$. cholerae are also luminous. Light organs, located variously depending on the species of fish, usually 
contain approximately $10^{9} \mathrm{cells} / \mathrm{ml}$, and the organ emits constant light (Haygood \& Nealson, 1984). Because of this high cell density, Haygood \& Nealson (1984) believe that free-living luminous vibrios recovered from seawater are "over-flow" from light organs of fish. Presently, the precise reason for this unusual species interaction is unknown.

\section{FISH POPULATIONS AFFECTED BY VIBRIO}

Vibrio spp. infect, and often cause disease in, a variety of estuarine and marine fish, some of which are listed in Table 3. Generally speaking, disease is attributable to some form of stress that renders the fish more susceptible. The disease that follows is typically a systemic infection known as vibriosis or some form of skin ulcer (Table 3).

Table 3. Selected marine fish known to be susceptible to Vibrio infection and disease

\begin{tabular}{|ll|}
\hline Fish & Disease \\
\hline Ayu & vibriosis, hemorrhagic disease \\
Akame & skin ulcers \\
Sharks & skin ulcers, vasculitis \\
Cod & skin ulcers, fin rot \\
Eels & vibriosis \\
Flounder & vibriosis \\
Gray mullet & fin rot \\
Salmon & vibriosis \\
Sea-bream & acute septicemia, vibriosis \\
Sole & red spot \\
Striped bass & vibriosis \\
Turbot & acute edema \\
\hline
\end{tabular}

Ayu. Ayu (Plecoglossus altivelis), a fish cultured in Japan, is susceptible to a variety of infections, including streptococcal and vibrio disease. Vibrio disease is usually a classic vibriosis caused by $V$. anguillarum (Jo \& Muroga, 1977; Kusuda et al., 1981; Aoki \& Kitao, 1978). However, $V$, cholerae serovar non-01 has also been implicated in ayu disease (Muroga et al., 1979b; Yamanoi et al., 1980).

A k a me. Wild akame (Liza akame) were observed by Muroga (1979) to have skin ulcers caused by a parasitic copepod, Caligus orientalis. The copepod was detected on 35 of 36 akame examined, with an infestation rate of 27 copepods per fish. Several species of bacteria were isolated from the lesions, including Vibrio spp.

Cod. Atlantic cod (Gadus morhua) are susceptible to vibriosis, especially when exposed to polluted waters. Larsen et al. (1978) observed that cod living in Danish coastal waters suffered from a specific ulcer syndrome, but only when exposed to water contaminated with municipal sewage or effluent from sugar and cellulose plants. Larsen et al. (1978) were not able to elucidate etiology of the primary lesion, but could demonstrate that $V$. anguillarum infected the ulcer thereby establishing a generalized vibriosis. In a later study, it was shown that $V$. anguillarum could not elicit the disease, even when the organism was inoculated into the animal by a variety of routes (Jenson \& Larsen, 1982). Interestingly, an icosahedral virus isolated from the diseased cod was 
shown to produce the ulcer syndrome. Thus, it was hypothesized that the icosahedral virus was necessary to initiate pathogenesis, with $V$. anguillarum playing a role in progression of the disease. Most interesting was the relationship between the incidence of $V$. anguillarum and wastewater discharge. The frequency of occurrence of $V$. anguillarum was highest in areas of known contamination, and the numbers of $V$. anguillarum in water and sediment immediately increased in direct response to effluent discharge from a sugar plant (Larsen et al., 1978). Robohm et al. (1979) also studied the effect of pollution on fish disease, and were able to demonstrate significantly higher antibody titers to $V$. anguillarum in flounder collected from the New York Bight apex than in flounder from unpolluted coastal waters.

In a study of captive Atlantic cod, it was observed that 320 of $621 \mathrm{cod}$ died from fin rot, over an 8-year period. Most deaths occurred within 2 months after capture, and death was probably due to excessive blood loss associated with fin erosion. Three genera of bacteria were isolated from the infected tissues, mainly Pseudomonas spp., but also Aeromonas and Vibrio spp. (Khan et al., 1981).

E e l s . Cultivated eels are susceptible to a variety of bacterial infections, producing several clinical symptoms. Correct diagnosis is, therefore, dependent on isolation and identification of the pathogen (Nishibuchi et al., 1980). In addition to diseases caused by Aeromonas and Pseudomonas spp., discussed above, eels are susceptible to infection with $V$. anguillarum and $V$. vulnificus biogroup 2 (Nishibuchi et al., 1980; Tison et al., 1982). Rodsaether et al. (1977) concluded that $V$. anguillarum is part of the normal flora of eels (A. anguilla), and that copper contamination changes the commensal association between fish and the bacterium to pathogenicity. In contrast, is the finding of Kanai et al. (1977) who reported they could not recover Vibrio spp. from healthy eels (A. japonica), except during the month of October. However the results of Kanai et al. (1977) must be seriously questioned, with regard to Vibrio recovery, since the recovery medium used was nutrient agar without salt added. Vibrios, in general, require $\mathrm{NaCl}$ for growth (Singleton et al., 1982).

Flou nder. Both winter flounder (Pseudopleuronectes americanus) and smooth flounder (Liopsetta putnami) are susceptible to infection and disease caused by $V$. anguillarum (Hoornbeek et al., 1982; Watkins et al., 1981; Robohm et al., 1979). Myxobacter and protozoan parasites have also been shown to be associated with flounder mortality observed by Hoormbeek et al. (1982), but it was not stated whether there were mutualistic, mixed infection, or vector relationships with $V$, anguillarum. Watkins et al. (1981) studied laboratory infections of winter flounder, and found that the $\mathrm{LD}_{50}$ was lower (by 2-3 logs) for challenge by injection of $V$. anguillarum, compared with oral challenge. In addition, the mean $\mathrm{LD}_{50}$ for fish collected during the winter was about 3 logs less than that for specimens collected in the summer.

Gr a y m u ll e t. Healthy gray mullet (Mugil cephalus) were shown by Hamid et al. (1978) to carry Enterobacter, Bacillus, and Micrococcus spp. as the principal intestinal bacteria. When transferred to seawater, the dominant genera recovered from the fish included Vibrio, Pseudomonas, and Aeromonas. In subsequent studies, it was shown that the intestinal Vibrio and Enterobacter spp. were strongly proteolytic and also capable of producing amylase, chitinase, and lecithinase (Hamid et al., 1979). In a later study, Kakimoto \& Mowlah (1980) showed these gray mullet isolates to be $V$. anguillarum and E. aerogenes. 
Minchew \& Yarbrough (1977) demonstrated that experimental crude oil spills significantly increased the incidence of fin rot in mullet, from $6 \%$ in clean, control ponds to $96 \%$ in ponds contaminated with $4-5 \mu \mathrm{l} / 1$ (ppm) crude oil. A Vibriosp. was considered to be the primary pathogen involved in the oil-associated fin erosion. Interestingly, Hada \& Sizemore (1981) showed that the incidence of Vibrio spp. in the water column near a Gulf of Mexico oil field production platform was much greater than incidence in a noncontaminated control area. Furthermore, these vibrios were more likely to contain one or more plasmids.

Salmonids. Vibriosis of salmonid fish, both wild and cultured, is a serious disease of worldwide distribution and importance. As discussed above, both $V$. anguillarum and $V$. ordalii can cause vibriosis in salmon (Schiewe, 1983; Crosa et al., 1977; Harrell et al., 1976) although in specific cases other Vibrio spp. have been isolated (Tajima et al., 1981).

Yoshimizu et al. $(1976 a, 1976 \mathrm{~b}, 1976 \mathrm{c})$ published a series of studies on the intestinal microflora of salmonids. Masu salmon reared in freshwater were found to contain Aeromonas as the predominant bacterial genus in the intestine. When the fish were moved to seawater, a succession in the bacterial flora composition occurred, going from Aeromonas to Pseudomonas to Vibrio dominance (Yoshimizu et al., 1976a). Yoshimizu et al. (1976b) also studied the intestinal microflora of salmonids living in the Bering Sea, as well as bacteria associated with seawater and zooplankton samples collected from the Bering Sea. Vibrio spp. were found to be dominant in the intestine of salmonids. The microbial flora of the animals differed from that isolated from seawater and zooplankton. Finally, Yoshimizu et al. (1976c) compared the intestinal microflora of adult pink salmon (Oncorhynchus gorbuscha) with that of anadromous chum salmon (O. keta) and cultured masu salmon (O. masu). Predominant bacterial genera in the anadromous pink and chum salmon were Vibrio, Pseudomonas, and Aeromonas. In the masu salmon, Aeromonas dominated. It would appear, therefore, that Vibrio spp. comprise the normal intestinal flora of salmonids, with exposure to seawater serving as a selective pressure.

Sawyer et al. (1979) studied the comparative susceptibility of atlantic salmon (Salmo salar) and coho salmon (Oncorhynchus kisutch) to $V$. anguillarum administered via water. Exposure to $\leq 105 \mathrm{cells} / \mathrm{ml}$ for $1 \mathrm{~h}$ at $10^{\circ} \mathrm{C}$ and at $15^{\circ} \mathrm{C}$ resulted in the death of 80 to $100 \%$ of both salmonid species. It was concluded that newly released smolts could encounter lethal concentrations of $V$. anguillarum if the animals were released in Maine (USA) estuaries.

Finally, with regard to salmon, MacMillan et al. (1980) studied infection of chum salmon (O. keta) suffering from erythrocytic necrosis virus (ENV). Fish infected with ENV were less tolerant of dissolved oxygen depletion, exhibited characteristic cytopathogenic effects in erythroid cells, and were at least 3 times more susceptible to vibriosis.

Sea-bream. Acute septicemia was observed by Colorni et al. (1981) to be a frequent cause of mortality among gilthead sea-bream (Sparus aurata) raised in a laboratory at Elat, Israel. The most frequently isolated bacterium was $V$. alginolyticus, although 6 distinct strains were identified. Yasunaga \& Yamamoto (1977) studied a similar outbreak among cultured red sea-bream (Pagrus major) and isolated several cultures of Vibrio that were able to be classified as 3 distinct groups. Iwata et al. (1978), in a study of the virulence of $V$. alginolyticus for red sea-bream, discovered that red seabream mortality increased if rotifers were present in the seawater along with the $V$. 
alginolyticus. If Chlorella was mixed with $V$. alginolyticus, mortality was less than if $V$. alginolyticus was present alone. When all three microorganisms, $V$. alginolyticus, Chlorella, and rotifers, were mixed in an aquarium, the number of $V$. alginolyticus increased as the rotifers grazed and consumed the Chlorella.

$\mathrm{S} \mathrm{h}$ a r k s. Diseases of sharks have been described recently (Grimes et al., 1984a, b, c), with Vibrio spp. definitely involved in certain of the shark infections reported. Genera other than Vibrio have been isolated from shark specimens examined in our laboratory, and these bacteria are now being characterized. Cheung et al. (1982) isolated and described a vibrio associated along with a trematode (Dermophthirius nigrellii) (Cheung \& Ruggieri, 1983) which induced ulcers in captive lemon sharks. Unfortunately, the few biochemical characteristics reported by Cheung et al. (1982) are insufficient to classify their isolate as a Vibrio sp.; the characteristics reported also fit the description for Aeromonas hydrophila and A. salmonicida. Vibrio spp. have been isolated from the great white shark (Carcharodon carcharias), but not in association with specific disease (J. Buck, pers. comm).

Sol e. Vibrio spp. can cause disease in sole. Williams \& Caldwell (1978) reported that laboratory-reared English sole (Parophyrs vetulus) experienced vibrio mortality, and Fluechter (1979) described a red spot disease of the common sole (Solea solea) caused by a Vibrio sp.

Striped bass. Substantial losses of striped bass (Morone saxatilis) have occurred in the Chesapeake Bay during the last decade. Eight distinct biochemical groups of Vibrio spp. have been isolated from moribund striped bass (Toranzo et al., 1983a), two groups of which were identified as $V$. anguillarum (Toranzo et al., 1983b). Hetrick et al, (1984) found that the virulence of $V$. anguillarum for striped bass was directly influenced by age of the fish and water temperature. Exposure of the striped bass to sub-lethal chlorine levels $(0.05-0.20 \mathrm{mg} / \mathrm{l}$, total residual chlorine) did not affect susceptibility to infection. Virulence $\left(\mathrm{LD}_{50}\right)$, cytotoxicity, hemolytic activity, and adhesiveness of $V$. anguillarum have been studied (Toranzo et al, 1983b), as well as plasmid content and envelope protein profiles (Toranzo et al, 1983a). Details of this work are discussed in the section on mechanisms of virulence (vide infra).

Turbot. A vibriosis described by Horne et al. (1977) as an acute edematous disease and characterized by orbital and abdominal swelling and high mortality (20\%), occurred in turbot (Scophthalmus maximus) in Scotland. V. anguillarum was isolated, in pure culture, from all organs of all of the fish examined. Antibiotic therapy was not successful, but reduction of the water temperature to less than $10^{\circ} \mathrm{C}$ reduced mortality from $30 \%$ to $5 \%$. Austin (1982) studied the surface bacterial flora of healthy turbot, as well as specimens collected from turbot suspected of having vibriosis, and failed to isolate $V$, anguillarum from any of the samples.

\section{VIRULENCE MECHANISMS}

The most recent work on Vibrio diseases of marine fish has dealt with elucidation of virulence mechanisms. Much of this exciting work involves molecular genetics and the bulk of the studies have been directed toward $V$. anguillarum and $V$. ordalii because of the extensive involvement of these pathogens in fish diseases throughout the world.

In 1977, Crosa, Schiewe, and Falkow (Crosa et al., 1977) discovered that high 
virulence strains of $V$. anguillarum, i.e., strains that cause death of infected salmonids, possess a large plasmid with a mass of ca 47 megadaltons (Mdal). This plasmid, pJM1, was found in all high virulence strains examined, judged by plasmid homology experiments (Crosa et al., 1977). Furthermore, cured strains lost their virulence (Crosa et al., $1977,1980)$. Crosa $(1979,1980)$ subsequently demonstrated that the plasmid pJM1 codes for production of a highly efficient iron sequestering system which allows $V$. anguillarum to obtain iron necessary for metabolism, even in the presence of host defense factors that have high affinity for unbound iron (i.e., transferrin and lactoferrin, iron chelating proteins present in body fluids and secretions of vertebrates). Briefly, the iron sequestering system consists of a low molecular weight siderophore and two outer membrane proteins, OM2 and OM3, which have molecular weights of 86,000 and 79,000 daltons, respectively (Crosa et al., 1983). Both the siderophore and OM2 are coded by pJM1; OM3 is chromosome product of unknown involvement in the system. The siderophore diffuses into the environment and complexes with iron, even iron that has been bound by vertebrate transferrin (Crosa et al., 1983). The siderophore-iron complex is attached to outer membrane protein OM2, where iron is then presumably transported into the cell (Crosa et al., 1983).

Trust et al. (1981) studied the ability of marine vibrios, including $V$. anguillarum, to agglutinate erythrocytes and to resist the bactericidal effect of normal (nonimmune) serum. High virulence strains of $V$. anguillarum exhibited resistance to normal trout (Salmo gairdneri) serum and agglutinated trout erythrocytes, even in the presence of mannose. However, neither serum resistance nor mannose-resistant hemagglutination was coded by virulence plasmid pJM1.

Recently, Schiewe \& Crosa (1981) demonstrated the presence of a $20 \mathrm{Mdal}$ plasmid, pMJ101, in V. ordalii. Homology was not observed between pJM1 and pMJ101, and the function of pMJ101 was concluded to be cryptic. Interestingly, the presence of this 20-Mdal plasmid is universal in all strains of $V$. ordalii examined thus far, and it is the only plasmid present.

Toranzo et al. (1983a, b, c) extended the molecular genetic and virulence studies of $V$. anguillarum to strains isolated from moribund striped bass ( $M$. saxatilis) captured in Chesapeake Bay, In a study of molecular factors associated with virulence, Toranzo et al. (1983b) found that, of 8 distinct groups of Vibrio spp. isolated from striped bass and Chesapeake Bay water samples, two vibrio groups were pathogenic for striped bass. These two groups were identified as $V$. anguillarum, based on biochemical tests and DNA homology with reference strains. None of the $V$. anguillarum strains contained detectable plasmids, although all strains were capable of growing under conditions of iron limitation and in normal fish serum. When grown under iron limitation, new outer membrane protein bands appeared in SDS-polyacrylamide gels. Furthermore, the striped bass $V$. anguillarum strains were shown to synthesize a sideophore, and preliminary experiments revealed the presence of chromosomal DNA sequences that hybridized with pJM1 (Toranzo et al., 1983b). In a related study, Toranzo et al. (1983c) showed that the striped bass $V$, anguillarum strains were not cytotoxic for a chinook salmon embryo cell culture, although all strains were hemolytic for striped bass, trout, and sheep erythrocytes. Munn (1978) has also investigated hemolysin production by $V$. anguillarum, and he found the toxin to be a thermolabile protein produced in stationary growth phase. In addition, the $V$. anguillarum strains studied by Toranzo et al. (1983c) also 
produced strong hemagglutinins for trout, striped bass, and other erythrocytes. Adhesion of $V$. anguillarum to rainbow trout intestinal tissue sections was recently examined by Horne \& Baxendale (1983). They found that maximum attachment occurred within $100 \mathrm{~min}$, and that all regions of the gut were subject to heavy (ca. $10^{3}$ cells per $\mathrm{cm}^{2}$ ) colonization.

Kreger (1984) studied the virulence of $V$.damsela, and detected the production of a cytolytic toxin. The toxin has a molecular weight of 57,000 daltons and is antigenically distinct from toxins produced by $V$, cholerae, $V$. parahaemolyticus, and $V$. vulnificus. Using mouse erythrocytes as the cytolytic assay system, Kreger found that partially purified cytolysin from an unnamed fish isolate contained ca. $3 \times 10^{5}$ hemolytic units per $\mathrm{mg}$ of protein. Mice injected subcutaneously with $1 \mathrm{LD}_{50}(1,000$ hemolytic units) of the cytolysin became lethargic, had ruffled fur, developed encrustations around the eyelids, and exhibited severe local edema at the site of inoculation; mice so injected usually died within $24 \mathrm{~h}$. To date, there have been no reported virulence studies conducted on fish.

Both $V$. vulnificus (Smith \& Merkel, 1982) and $V$. anginolyticus (Long et al., 1981) produce collagenase which presumably aids in the cutaneous infections caused by these two vibrios. Other Vibrio spp. have also been shown to be capable of elaborating collagenase, but the role of the proteolytic enzyme in pathogenesis has not been reported (Merkel \& Dreisbach, 1978).

\section{TREATMENT AND PREVENTION}

\section{Antimicrobial agents}

Attempts to control fish disease have been reported almost since development of the first clinically successful antimicrobics in the late 1940's (Snieszko et al., 1952). Treatment of freshwater fish species, wild or cultured, is relatively easy, since one is usually dealing with a small body of water. Saltwater species on the other hand, unless they are cultured or confined, present obvious difficulties because of the immense size of the habitat. Generally speaking, the most widely used antimicrobials have been the sulfonamides, the nitrofurans, the tetracyclines, and, more recently, substituted quinolines. Regardless of what antimicrobic is used, bacteria can develop resistance by aquisition of R plasmids (Aoki et al., 1980; Kimura et al., 1983; Toranzo et al., 1983a).

One of the more useful antimicrobials has been the combination of two bacteriostatic chemicals, sulfonamides and trimethoprim. In concert, these two chemicals have a synergistic effect, and can be used effectively to control resistant organisms (Kimura et al., 1983; Sako \& Kusuda, 1978; Sako et al., 1979). Recently, Keck et al. (1980) reported that increased oxygen tension (ca $2.2 \mathrm{~atm}$.) markedly potentiated a bacteriostatic effect (i.e., lowered the minimum inhibitory concentration, MIC) of folic acid inhibitors, such as sulfonamides and trimethoprim-sulfonamides.

Some of the newer agents include piromidic acid (Tashiro et al., 1979), furanace (Egidius \& Andersen, 1979), and substituted quinolines, such as halquinol (Austin et al., 1981, 1982). Also, some degree of success in preventing transmission of several Gramnegative fish pathogens, including $V$. anguillarum, has been achieved by ultraviolet 
Table 4. Recommended rates of application of fish antimicrobics

\begin{tabular}{|lccll|}
\hline \multicolumn{1}{|c}{ Antimicrobic } & Dosage & Route & Target & Reference \\
\hline Piromidic acid & $10-40 \mathrm{mg} / \mathrm{kg}$ & oral & salmonids \& eels & Tashiro et al. (1979) \\
Sulfadoxine-TMP & $30 \mathrm{mg} / \mathrm{kg}$ & oral & ayu & Sako et al. (1979) \\
Sulfamethoxazole-TMP & $25 \mathrm{mg} / 1$ & bath & turbot & Austin et al. (1981) \\
Furanace & $2 \mathrm{mg} / 1$ & bath & rainbow trout & Egidius \& Andersen (1979) \\
Halquinol & $25 \mathrm{mg} / 1$ & bath turbot & Austin et al. (1982) \\
& $75 \mathrm{mg} / \mathrm{kg}$ & oral & turbot & Austin et al. (1982) \\
a & & & & \\
b wP-trimethoprim & & & & \\
\end{tabular}

irradiation of the fish culture water (Bullock \& Stuckey, 1977). In Table 4 are listed some of the more effective antimicrobials.

\section{Immunization}

As with antimicrobial therapy, immunization has also been practiced for many years (Snieszko \& Friddle, 1949; Krantz et al., 1963; Hayashi et al., 1964). Early attempts at immunization involved crude antigen preparations, if not simply whole cells, and was labor intensive. Recent approaches to immunization are novel and much more efficacious than the early procedures. A wide variety of antigen preparations, administered in different ways, have been tried and are presented in Table 5.

The simplest delivery system appears to be the administration of the vaccine by the oral route, usually with food. Kusuda et al. (1978) studied four different oral vaccines

Table 5. Summary of approaches to immunization against Vibrio anguillarum

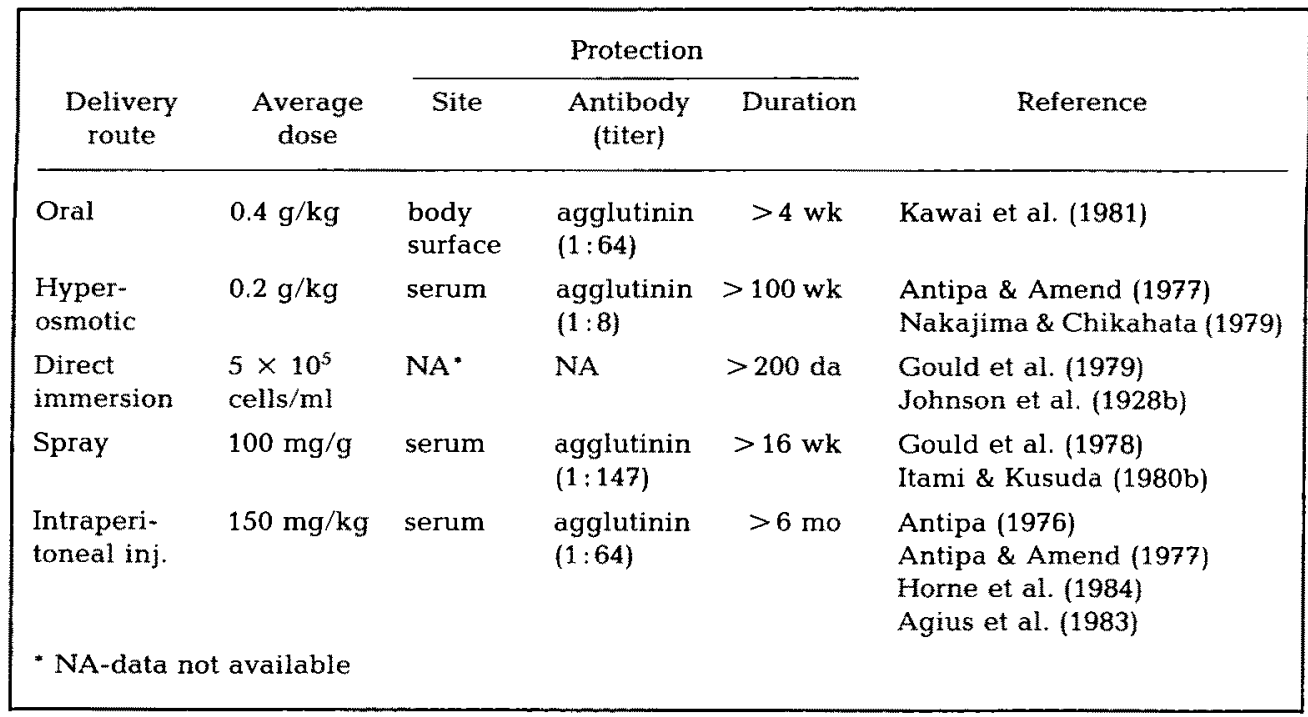


prepared from formalin-killed $V$. anguillarum: (1) formalin-killed cells, (2) formalinkilled, ultrasonicated cells, (3) formalin-killed, heated cells, and (4) formalin-killed cells mixed with Freund's incomplete adjuvant. The four bacterins were administered to cultured ayu ( $P$. altivelis) at a rate of $0.4 \mathrm{~g}$ (wet $w \mathrm{t}$.) of cells per $\mathrm{kg}$ body wt, per day. Formalin-killed and formalin-killed, ultrasonicated bacterins were the most effective, lowering mortality from $90 \%$ in controls to approximately $10 \%$. Interestingly, circulating antibody could not be detected. In a follow-up study, Kawai et al. (1981) compared orally immunized ayu with non-immunized controls to determine the site of immunity. Immunized fish were highly resistant to challenge with $V$. anguillarum by immersion, but were equally susceptible, as were the controls, when the challenge was by intramuscular injection. It was determined that the skin of immunized ayu was free from $V$. anguillarum, when challenged by immersion, and serological examination of the body surface mucus revealed an agglutinin titer of $1: 64$ (Kawai et al., 1981). Neither the serum nor the intestinal mucus of immunized fish contained increased agglutinin titers. It was concluced that the mechanism of immune resistance involved prevention of bacterial attachment by agglutinins secreted in the surface mucus (Kawai \& Kusuda, 1981).

Vaccination by direct immersion of fish has been practiced in the commercial sector by Antipa \& Amend (1977). They dipped the salmon (O. kisutch and O. tshawytscha) in a hyperosmotic salt solution, a step that was hypothesized to enhance antigen uptake. The salmon were next dipped in killed $V$. anguillarum antigen preparations, and immunized animals were compared with non-immunized controls and intraperitoneally-injected immune controls. Antipa \& Amend (1977) concluded that the hyperosmotic infiltration method of vaccine delivery afforded the best protection and yielded the most rapid rise in antibody titer. Croy \& Amend (1977) studied the hyperosmotic infiltration method of immunizing sockeye salmon (O. nerka) against vibriosis, using killed $V$. anguillarum as antigen. They found that pre-immersion of the fish in Hanks' balanced salt solution with $8 \% \mathrm{NaCl}$ was markedly superior to immunization without hyperosmotic treatment. In subsequent studies on immunizing against $V$. anguillarum, Lannan (1978) applied the hyperosmotic approach for chum salmon (O. keta) and Nakajima \& Chikahata (1979) tried it for ayu ( $P$. altivelus). Most recently, Aoki et al. (1984) modified the hyperosmotic approach by removing undesirable toxic components of $V$. anguillarum. Specifically, they formalized a culture and sedimented the cells by centrifugation to remove soluble toxic factors in the supernatant. The precipitated cells were used to immunize ayu previously immersed in a $5.32 \% \mathrm{NaCl}$ solution. Controls consisted of non-immunized and intraperitoneally immunized ayu. Removal of the supernatant increased the survival of immunized ayu. The conclusion was that an exotoxin was present in the formalized cultures. Upon intraperitoneal challenge with viable $V$. anguillarum, survival was found to be greatest (near $100 \%$ ) among ayu immersed in precipitated cells, next highest (60-70\%) among ayu injected intraperitoneally, and least (ca. $20 \%$ ) among nonimmunized controls. One month after immunization, no agglutinating titers were detected in the serum or mucus of fish immunized by immersion or in non-immunized controls. Intraperitoneally immunized ayu had elevated serum titers, but no anti$V$. anguillarum activity was detected in the mucus (Aoki et al., 1984).

Later studies revealed prior treatment with hyperosmotic salt immersion was unnecessary. Gould et al. (1979) obtained long-lasting immunity in sockeye salmon (O. nerka) 
by immersing the fish in formalin-killed $V$. anguillarum (ca $5 \times 10^{5}$ cells per $\mathrm{ml}$ of immersion solution), types I and II (i.e., $V$. anguillarum and $V$. ordalii, respectively). Mortality was reduced to $2 \%$, with little cross protection observed by immunization with the two different Vibrio bacterins. Bivalent immunization, i.e., simultaneous immersion in both bacterins, was as effective as type I and II bacterins individually applied (Gould et al., 1979). Johnson et al. (1982a, b) examined the direct immersion method as a means of immunizing the fry of different salmonids. In general, the best results were obtained with fry 1.0 to $2.5 \mathrm{~g}$, total body wt, and the immersion time required was ca 5 seconds. Direct immersion as a means of immunizing against vibriosis has also been applied to cultured ayu (Kusuda et al., 1980; Takeji et al., 1981) and to striped bass (Roberson et al., 1982). Roberson et al. (1982) used a 2-min immersion in $V$, anguillarum 0-antigen (acetone-ethanol extract), and enhanced antibody levels were detected in serum collected from the striped bass.

Spray, or shower, vaccination is basically a modification of direct immersion, in that fish are immunized by a high pressure spray directed at netted fish or at fish in shallow channels. This approach has been used successfully to immunize both ayu and salmonids against $V$, anguillarum (Gould et al., 1978; Itami \& Kusuda, 1978, 1980a, b; Johnson et al., 1982b). In general, immunity was comparable to that obtained with direct immersion, and better than that by oral (Gould et al., 1978).

Intraperitoneal injection is perhaps the most effective, in terms of producing a high degree of immunity, but is both expensive and labor intensive. It also subjects the fish to stress associated with handling. Single injections of $V$. anguillarum bacterins (heatkilled, formalin-killed, or both) gave significant protection in salmonids for over 7 months post-inoculation (Antipa, 1976). Sawyer \& Strout (1977) compared immunization with oxytetracycline treatment as methods for controlling vibriosis in coho salmon, and found intraperitoneal immunization significantly superior to antibiotic prophylaxis. Finally, Horne et al. (1982) compared intraperitoneal, direct immersion, and oral administration of formalized $V$. anguillarum to rainbow trout (Salmo gairdneri) using a vaccine containing $35 \mathrm{mg}$ (wet wt.) of bacterin per $\mathrm{ml}$ of vaccine and $2.5 \%$ (w/v) potassium aluminum sulfate adjuvant. The intraperitoneal route employed $100 \mu \mathrm{l}$. Fish were immersed for $30 \mathrm{~min}$ in a 10 -fold dilution for direct immersion. For oral route of entry, $3.5 \mathrm{mg}$ of bacteria were given with food over a 32-day period. After 85 days, all fish, including non-immunized controls, were challenged by intraperitoneal injection of $2 \times 10^{7}$ viable cells of $V$. anguillarum. Survival rates at 21 days after challenge were $93 \%$ for intraperitoneal delivery of the vaccine; $47 \%$ for direct immersion, $6 \%$ for oral, and $0 \%$ for controls. In a follow-up study, Agius et al. (1983) used a perchloric acid extract as the antigen preparation, and compared it to formalin-killed $V$. anguillarum cells as an immunizing agent. The antigen extract was concluded to be superior when intraperitoneal delivery was employed, but formalized cells were better in delivery by the oral route. Alum appears to offer little additional protection, leading Horne et al. (1984) to question the use of adjuvants.

In addition to improvements in methods of immunization, improvements have also been made in serological techniques. Roberson (1981) combined the methods of thin layer immunoassay and enzyme-linked immunosorbent assay (ELISA) to detect anti$V$. anguillarum antibody in striped bass immunized by intraperitoneal injection with 0 antigen. The sensitivity was found to be comparable to passive hemagglutination. 
Gosting et al. (1981) used an immunocytoadherence assay to monitor progression of the immune response in sockeye salmon immunized against $V$. anguillarum by immersion and intraperitoneal injection. Both delivery methods initiated an elevated immune adherence in less than 1 day, and the response persisted 1 week longer in injected than in immersed fish.

\section{CONCLUSION}

The understanding of Vibrio diseases of marine fish populations has increased significantly since the first description of $V$. anguillarum appeared in 1893 (Canestrini, 1893). We now recognize several Vibrio spp. as being capable of causing disease in fish. The number of species of Vibrio involved will no doubt increase as mariculture activities are extended. However, modern immunization techniques, more effective antimicrobials, and better understanding of the ecology of the genus Vibrio offer means for improved control of Vibrio disease. In the near future, it will be possible to prevent vibriosis by specific genetic manipulations of the pathogens (Colwell, 1983, 1984).

\section{LITERATURE CITED}

Agius, C., Horne, M. T. \& Ward, P. D., 1983. Immunization of rainbow trout, Salmo gairdneri Richardson, against vibriosis: comparison of an extract antigen with whole cell bacterins by oral and intraperitoneal routes. $-\mathrm{J}$. Fish Dis. 6, 129-134.

Akazawa, H., 1968. Bacterial disease of marine fishes. - Bull. Jap. Soc. scient. Fish. 34, 271-272.

Antipa, R., 1976. Field testing of injected Vibrio anguillarum bacterins in pen reared Pacific salmon. - J. Fish. Res. Bd Can. 33, 1291-1296.

Antipa, R. \& Amend, D. F., 1977. Immunization of Pacific salmon: comparison of intraperitoneal injection and hyperosmotic infiltration of Vibrio anguillarum and Aeromonas salmonicida bacterins. - J. Fish. Res. Bd Can. 34, 203-208.

Aoki, T. \& Kitao, T., 1978. Vibriosis of ayu. - Fish Pathol. 13, 19-24.

Aoki, T., Jo, Y. \& Egusa, S., 1980. Frequent occurrence of drug resistant bacteria in ayu (Plecoglossus altivelis) culture. - Fish Pathol. 15, 1-6.

Aoki, T., Kitao, T. \& Kawano, K., 1981. Changes in drug resistance of Vibrio anguillarum in cultured ayu, Plecoglossus altivelis Temminck and Schlegel, in Japan. - J. Fish Dis. 4, 223-230.

Aoki, T., Kitao, T., Fukudome, M., Takahashi, S. \& Egusa, S., 1984. Modification of the hyperosmatic infiltration method of vaccination against vibriosis in cultured ayu, Plecoglossus altivelis Temminck and Schlegel. - J. Fish Dis. 7, 149-156.

Austin, B., 1982. Taxonomy of bacteria isolated from a coastal marine fish rearing unit. $-\mathbf{J}$. appl. Bact. 53, 253-268.

Austin, B., Morgan, D. A. \& Alderman, D. J., 1981. Comparison of antimicrobial agents for control of vibriosis in marine fish. - Aquaculture 26, 1-12.

Austin, B., Johnson, C. \& Alderman, D. J., 1982. Evaluation of substituted quinolines for the control of vibriosis in turbot (Scophthalmus maximus). - Aquaculture 29, 227-239.

Belas, M. R. \& Colwell, R. R., 1982a. Scanning and electron microscope observation of the swarming phenomenon in Vibrio parahaemolyticus. - J. Bact. 150, 956-959.

Belas, M. R. \& Colwell, R. R., 1982b. Adsorption kinetics of laterally flagellated Vibrio. - J. Bact. $151,1568-1580$.

Bergman, A. M., 1909. Die rote Beulenkrankheit des Aals. - Ber. K. bayer. biol. Vers.-Stn 2, 10-54.

Blake, P. A., Weaver, R. E. \& Hollis, D. G., 1980. Diseases of humans (other than cholera) caused by vibrios. - A. Rev. Microbiol. 34, 341-367.

Bullock, G. L. \& Stuckey, H. M., 1977. UV treatment of water for destruction of 5 gram-negative bacteria pathogenic to fishes. - J. Fish. Res. Bd Can. 34, 1244-1249.

Burke, J. \& Rodgers, L., 1981. Identification of pathogenic bacteria associated with the occurrence of 
"red spot" in sea mullet, Mugil cephalus L., in south-eastern Queensland. - J. Fish Dis. 4, 153-159.

Canestrini, G., 1893. La malattia dominante delle anguille. - Atti Ist. veneto Sci. 7, 809-814.

Cheung, P. J. \& Ruggieri, G. D., 1983. Dermophthirius nigrellii n. sp. (Monogenea: Microbothriidae), an ectoparasite from the skin of the lemon shark, Negaprion brevirostris. - Trans. Am. microsc. Soc. 102, 129-134.

Cheung, P. J., Nigrelli, R. F., Ruggieri, G. D. \& Cilia, A., 1982. Treatment of skin lesions in captive lemon sharks, Negaprion brevirostris (Poey), caused by monogeneans (Dermophthirius sp.). - J. Fish Dis. $5,167-170$.

Colorni, A., Paperna, I. \& Gordin, H., 1981. Bacterial infections in gilthead sea-bream (Sparus aurata) cultured at Elat, Israel. - Aquaculture 23, 257-268.

Colwell, R. R., 1983. Biotechnology in the marine sciences. - Science, N. Y. 222, 19-24.

Colwell, R. R., 1984. The industrial potential of marine biotechnology. - Oceanus 27, 3-12.

Crosa, J. H., 1979. Vibrio anguillarum: An iron uptake mechanism as a factor of virulence. - Fish Health News $8,7-10$.

Crosa, J. H., 1980. A plasmid associated with virulence in the marine fish pathogen Vibrio anguillarum specifies an iron sequestering system. - Nature, Lond. 284, 566-568.

Crosa, J. H., Schiewe, M. H. \& Falkow, S., 1977. Evidence for plasmid contribution to the virulence of the fish pathogen Vibrio anguillarum. - Infect. Immun. 18, 509-513.

Crosa, J. H., Hodges, L. L. \& Schiewe, M. H., 1980. Curing of a plasmid is correlated with an attenuation of virulence in the marine fish pathogen Vibrio anguillarum. - Infect. Immun. 27, $897-902$.

Crosa, J. H., Walter, M. A. \& Potter, S. A., 1983. The genetics of plasmid-mediated virulence in the marine fish pathogen Vibrio anguillarum. In: Bacterial and viral diseases of fish, molecular studies. Ed. by J. H. Crosa. Univ. of Washington, Seattle, 21-30.

Croy, T. R. \& Amend, D. F., 1977. Immunization of sockeye salmon (Oncorhynchus nerka) against vibriosis using the hyperosmotic infiltration technique. - Aquaculture 12, 317-326.

Egidius, E. \& Andersen, K., 1979. The use of Furanace against vibriosis in rainbow trout Salmo gairdneri Richardson in salt water. - J. Fish Dis. 2, 79-80.

Fluechter, J., 1979. Identification and treatment of diseases in the common sole (Solea solea). Aquaculture 16, 271-274.

Franca, S. M. C., Gibbs, D. L., Samuels, P. \& Johnson, W. D. Jr., 1980 . Vibrio parahaemolyticus in Brazilian coastal waters. - J, Am. med. Ass. 244, 587-588.

Gauthier, M. J. \& Clement, R., 1979. Experimental study of the transfer of Vibrio parahaemolyticus biotype 2 from water and sediments to organisms in benthic marine food chains, - Can. J. Microbiol. 25, 499-507.

Gilmore, A., 1977. Characteristics of marine vibrios isolated from fish farm tanks. - Aquaculture 11, $51-62$.

Gjerde, J. \& Boe, B., 1981. Isolation and characterization of Vibrio alginolyticus and Vibrio parahaemolyticus from the Norwegian coastal environment. - Acta vet. scand. 22, 331-343.

Gosting, L., Mirando, D. M. \& Gould, R. W., 1981. Antigen binding cells in the peripheral blood of sockeye salmon (Oncorhynchus nerka) induced by immersion or intraperitoneal injection of Vibrio anguillarum bacteria. - J. Fish Biol. 19, 83-86.

Gould, R. W., O'Leary, P. J., Garrison, R. L., Rohovec, J. S. \& Fryer, J. L., 1978. Spray vaccination: A method for the immunization of fish. - Fish Pathol. 13, 63-68.

Gould, R. W., Antipa, R. \& Amend, D. F., 1979. Immersion vaccination of sockeye salmon (Oncorhynchus nerka) with two pathogenic strains of Vibrio anguillarum. - J. Fish. Res. Bd Can. 36, 220-225.

Grimes, D. J., Stemmler, J., Hada, H., May, E. B., Maneval, D., Hetrick, F. M., Jones, R. T., Stoskopf, M. \& Colwell, R. R., 1984a. Vibrio species associated with mortality of sharks held in captivity, Microb. Ecol. 10 (In press).

Grimes, D. J., Colwell, R. R., Stemmler, J., Hada, H., Maneval, D., Hetrick, F. M., May, E. B., Jones, R. T. \& Stoskopf, M., 1984b. Vibrio species as agents of elasmobranch disease. - Helgoländer Meeresunters. 37, 309-315.

Grimes, D. J., Gruber, S. H. \& May, E. B., 1984c. Experimental infection of lemon sharks, Negaprion brevirostris, with Vibrio species. - J. Fish Dis. (Submitted). 
Hada, H. S. \& Sizemore, R. K., 1981. Incidence of plasmids in marine Vibrio spp. isolated from an oil field in the Northwestern Gulf of Mexico. - Appl. environ. Microbiol. 41, 199-202.

Hamid, A., Sakata, T. \& Kakimoto, D., 1978. Microflora in the alimentary tract of gray mullet. Part 2. A comparison of the mullet intestinal microflora in fresh water and sea water. - Bull. Jap. Soc. scient. Fish. 44, 53-58.

Hamid, A. Sakata, T. \& Kakimoto, D., 1979. Microflora in the alimentary tract of gray mullet. Part 4. Estimation of enzymic activities of the intestinal bacteria. - Bull. Jap. Soc. scient. Fish. 45 , 99-106.

Harrell, L. W., Novotny, A. J., Schiewe, M. H. \& Hodgins, H. O., 1976. Isolation and description of two vibrios pathogenic to Pacific salmon in Puget Sound, Washington. - Fish. Bull. U. S. 74, $447-449$.

Hastings, J. W. \& Nealson, K. H., 1977. Bacterial bioluminescence. - A. Rev. Microbiol. 31, $549-595$.

Hayashi, K., Kobayashi, S., Kamata, T. \& Ozaki, H., 1964. Studies on the vibrio disease of rainbow trout (Salmo gairdneri irideus) II. Prophylactic vaccination against the vibrio disease. - J. Fac. Fish., pref. Univ. Mie. 6, 181-191.

Haygood, M. G. \& Nealson, K. H., 1984. Effects of iron on bacterial growth and luminescence: Ecological implications. In: Current perspectives in microbial ecology. Ed. by M. J. Klug \& A. Reddy. Amer. Soc. Microbiol., Washington, D.C., 56-61.

Hetrick, F. M., Hall, L. W. Jr., Wolski, S., Graves, W. C., Roberson, B. S. \& Burton, D. T., 1984. Effect of exposure of striped bass (Morone saxatilis) to chlorine on their susceptibility to Vibrio anguillarum. - Can. J. Fish. aquat. Sci. (In press).

Hiratsuka, M., Saitoh, Y. \& Yamane, N., 1980. Isolation of Vibrio alginolyticus from a patient with acute enterocolitis. - Tohoku J. exp. Med. 132, 469-472.

Hoornbeek, F. K., Sawyer, P. J. \& Sawyer, E. S., 1982. Growth of winter flounder Pseudopleuronectes americanus and smooth flounder Liopsetta putnami in heated and unheated water. Aquaculture 28, 363-374.

Horne, M. T., 1982. The pathogenicity of Vibrio anguillarum (Bergman). In: Microbial disease of fish. Ed. by R. J. Roberts. Acad. Press, New York, 171-187.

Horne, M. T. \& Baxendale, A., 1983. The adhesion of Vibrio anguillarum to host tissues and its role in pathogenesis. - J. Fish Dis. 6, 461-471.

Horne, M. T., Richards, R. H., Roberts, R. J. \& Smith, P. C., 1977. Per acute vibriosis in juvenile turbot (Scophthalmus maximus). - J. Fish Biol. 11, 355-362.

Horne, M. T., Tatner, M., McDerment, S., Agius, C. \& Ward, P., 1982. Vaccination of rainbow trout, Salmo gairdneri Richardson, at low temperatures and the long-term persistence of protection. J. Fish Dis. 5, 343-345.

Horne, M. T., Roberts, R. J., Tatner, M. \& Ward, P., 1984. The effects of the use of potassium alum adjuvant in vaccines against vibriosis in rainbow trout, Salmo gairdneri Richardson. - J. Fish Dis. 7, 91-99.

Huq, A., Small, E. B., West, P. A., Huq, M. 1., Rahman, R. \& Colwell, R. R., 1983. Ecological relationships between Vibrio cholerae and planktonic crustacean copepods. - Appl. environ. Microbiol. 45, 275-283.

Itami, T. \& Kusuda, R., 1978. Efficacy of a vaccination by spray administration against vibriosis in cultured ayu. - Bull. Jap. Soc. scient. Fish. 44, 1413-1414.

Itami, T. \& Kusuda, R., 1980a. Studies on spray vaccination against vibriosis in cultured ayu (Plecoglossus altivelis). 1. Effect of bentonite and $\mathrm{pH}$ on vaccination efficacy. - Bull. Jap. Soc. scient. Fish. 46, 533-536.

Itami, T. \& Kusuda, R., 1980b. Studies on spray vaccination against vibriosis in cultured aya (Plecoglossus altivelis). 2. Duration of vaccination efficacy and effect of different vaccine preparations. - Bull. Jap. Soc. scient. Fish. 46, 699-704.

Iwata, K., Yanohara, Y. \& Ishibashi, O., 1978. Studies on factors related to mortality of young red sea-bream (Pagrus major) in the artifical seed production. - Fish Pathol. 13, 97-102.

Jensen, N. J. \& Larsen, J. L., 1982. The ulcus syndrome in cod Gadus morhua. 4. Transmission experiments with 2 viruses isolated from cod and Vibrio anguillarum. - Nord. VetMed. 34, 136-142.

Jo, Y. \& Muroga, K, 1977. Studies on vibriosis in ayu. Part 1. Virulence of a culture of Vibrio anguillarum. - Fish Pathol. 12, 151-156. 
Johnson, K. A., Flynn, J. K. \& Amend, D. F., 1982a. Onset of immunity in salmonid fry vaccinated by direct immersion in Vibrio anguillarum and Yersinia ruckeri bacterins. - J. Fish Dis. 5, $197-206$.

Johnson, K. A., Flynn, J. K. \& Amend, D. F., 1982b. Duration of immunity in salmonids vaccinated by direct immersion with Yersinia ruckeri and Vibrio anguillarum bacterins. - J. Fish Dis. $5_{s}$ $207-214$.

Joseph, S. W., Colwell, R. R. \& Kaper, J. B., 1982. Vibrio parahaemolyticus and related halophilic vibrios. - CRC crit. Rev. Microbiol. 10, 77-124.

Kakimoto, D. \& Mowlah, A. H., 1980. Microflora in the alimentary tract of gray mullet (Mugil cephalus). 8. Utilization of amino acids by Vibrio and Enterobacter isolates. - Mem. Fac. Fish. Kagoshima Univ. 29, 349-354.

Kanai, K. Wakabayashi, H. \& Egusa, S, 1977. Comparison of intestinal microflora between healthy and diseased pond cultured eels. - Fish Pathol, 12, 199-204.

Kaneko, T. \& Colwell, R. R., 1978. The annual cycle of Vibrio parahaemolyticus in Chesapeake Bay. - Microb. Ecol. 4, 135-155.

Kawai, K. \& Kusuda, R., 1981. Mechanisms of protection in ayu (Plecoglossus altivelis) orally vaccinated for vibriosis. 1. Protection activity in body surface mucus. - Fish Pathol. 16, 1-8.

Kawai, K. Kusuda, R. \& Itami, T., 1981. Mechanisms of protection in ayu (Plecoglossus altivelis) orally vaccinated for vibriosis. - Fish Pathol. 15, 257-262.

Keck, P. E., Gottlieb, S. F. \& Conley, J., 1980. Interaction of increased pressures of oxygen and sulfonamides on the in vitro growth of pathogenic bacteria. - Undersea biomed. Res. 7, 95-106.

Khan, R. A., Campbell, J. \& Lear, H., 1981. Mortality in captive Atlantic cod Gadus morhua associated with fin rot disease, - J. Wildl. Dis, 17, 521-528.

Kimura, T., Yoshimizu, M. \& Wada, M., 1983. In vitro antibacterial activity of the combination of sulphadiazine and trimethoprim on bacterial fish pathogens. - J. Fish Dis. 6, 525-532.

Krantz, G. E., Reddecliff, J. M. \& Heist, C. E., 1963. Development of antibodies against Aeromonas salmonicida in trout. - J. Immun. 91, 757-760.

Kreger, A. S., 1984. Cytolytic activity and virulence of Vibrio damsela. - Infect. Immun. 44,326-331.

Kusuda, R., Kawai, K., Jo, Y., Akizuki, T., Fukunaga, M. \& Kotake, N., 1978. Efficacy of oral vaccination for vibriosis in cultured ayu. - Bull. Jap. Soc. scient. Fish. 44, 21-26.

Kusuda, R., Sako, H. \& Kawai, K., 1979. Classification of vibrios isolated from diseased fishes. Part 1. On the morphological and biochemical properties. - Fish Pathol. 13, 123-138.

Kusuda, R., Kawai, K. \& Itami, T., 1980. Efficacy of bath immunization against vibriosis in cultured ayu (Plecoglossus altivelis). - Bull. Jap. Soc. scient. Fish. 46, 1053.

Kusuda, R., Sugiyama, A., Kawai, K., Inada, Y. \& Yoneda, M., 1981. Pathogenicity of Streptococcus sp. and Vibrio anguillarum in cultured ayu. - Bull. Jap. Soc. scient. Fish. 47, 993-998.

Lall, R., Sen, D., Saha, M. R., Bose, A. K, De, S. P., Palchowdhury, N. C. \& Pal, S. C., 1979. Prevalence of Vibrio parahaemolyticus in Port-Blair, India. - Indian J, med. Res. 69, $217-221$.

Lannan, J. E., 1978. Vibriosis vaccination of chum salmon by hyperosmotic infiltration. - Progve Fish Cult. 40, 43-45.

Larsen, J. L., Jensen, N. J. \& Christensen, N. D., 1978. Water pollution and the ulcer syndrome in the cod Gadus morhua. - Vet. Sci. Commun. 2, 207-216.

Lhuillier, M., 1977. Vibrio parahaemolyticus and Vibrio alginolyticus isolation, diagnosis and epidemiology: 74 strains isolated in Madagascar. - Archs Inst. Pasteur Madagascar 45, $27-50$.

Long, S., Mothibeli, M. A., Robb, F. T. \& Woods, D. R., 1981. Regulation of extracellular alkaline protease activity by histidine in a collagenolytic Vibrio alginolyticus strain. - J. gen. Microbiol. 127, 193-199.

Love, M., Teebken-Fisher, D., Hose, J. E., Farmer III, J. J., Hickman, F. W. \& Fanning, G. R., 1981. Vibrio damsela, a marine bacterium, causes skin ulcers on the damselfish Chromis punctipinnis. - Science, N. Y. 214, 1139-1140.

MacMillan, J. R., Mulchay, D. \& Landolt, M., 1980. Viral erythrocytic necrosis. Some physiological consequences of infection in chum salmon (Oncorhynchus keta). - Can. J. Fish. aquat. Sci. 37, 799-804.

Merkel, J. R. \& Dreisbach, J. H., 1978. Purification and characterization of a marine bacterial collagenase. - Biochemistry 17, 2857-2863.

Minchew, C. D. \& Yarbrough, J. D., 1977. The occurrence of fin rot in mullet (Mugil cephalus) 
associated with crude oil contamination of an estuarine pond ecosystem. - J. Fish Biol. 10 , 319-323.

Miyazaki, T., Jo, Y., Kubota, S. S. \& Egusa, S., 1977. Histopathological studies on vibriosis of the Japanese eel Anguilla japonica. Part 1. Natural infection. - Fish Pathol. 12, 163-170.

Munn, C. B, 1978. Haemolysin production by Vibrio anguillarum. - FEMS Microbiol. Lett. 3, $265-268$

Muroga, K., 1979. Ulcer disease of akame (Mugilidae) in the estuary of the river Ashida, Japan. Fish Pathol. 13, 163-168.

Muroga, K., Jo, Y. \& Nishibuchi, M., 1976. Vibrio anguillarum isolated from the European eel Anguilla anguilla cultured in Japan. - J. Fac. Fish Anim. Husb. Hiroshima Univ. 15, $29-34$.

Muroga, K., Yoneyama, N. \& Jo, Y., 1979a. Vibriostatic agent resistant Vibrio anguillarum isolated from ayu. - Fish Pathol. 13, 159-162.

Muroga, K., Takahashi, S., Yamanoi, H. \& Nishibuchi, M., 1979b. Noncholera vibrio Vibrio anguillarum isolated from diseased ayu Plecoglossus altivelis. - Bull. Jap. Soc. scient. Fish. 45 , $829-834$.

Nair, G. B., Abraham, M. \& Natarajan, R., 1980. Distribution of Vibrio parahaemolyticus in finfish harvested from Porto Novo (S. India) environs: a seasonal study. - Can. J. Microbiol. 26, $1264-1269$.

Nakajima, M, \& Chikahata, H., 1979. Efficiency of oral and hyperosmotic vaccinations for vibriosis in ayu (Plecoglossus altivelis). - Fish Pathol. 14, 9-14.

Natarajan, R., Abraham, M. \& Nair, G. B., 1980. Distribution of Vibrio parahaemolyticus in the Porto-Novo, India environment. - Indian J. med. Res. 71, 679-687.

Nishibuchi, M., Muroga, K., Seidler, R. J. \& Fryer, J. L., 1979. Pathogenic Vibrio isolated from cultured eels. IV. Deoxyribonucleic acid studies. - Bull. Jap. Soc. scient. Fish. 45, 1469-1473.

Nishibuchi, M., Muroga, K. \& Jo, Y., 1980. Pathogenic Vibrio isolated from cultured eels. 6. Diagnostic tests for the disease due to present bacterium. - Fish Pathol, 14, 125-132.

Novitsky, J. A. \& Morita, R. Y., 1976. Morphological characterization of small cells resulting from nutrient starvation of a psychrophilic marine Vibrio. - Appl. environ. Microbiol. 32, 617-622.

Oliver, J. D., Warner, R. A. \& Cleland, D. R., 1983. Distribution of Vibrio vulnificus and other lactose-fermenting vibrios in the marine environment. - Appl. environ. Microbiol, 45, 985-998.

Ortiz, J. S. \& Decker, D. L., 1976. Demonstration of agglutinating antibodies against Vibrio parahaemolyticus in the yellowtail flounder, Limanda ferruginea, - Health Lab. Sci. 13, 197-202.

Qadri, R. B. \& Zuberi, R., 1977. Survey on the occurrence of Vibrio parahaemolyticus and Vibrio alginolyticus in fish and shellfish from the Karachi, Pakistan coastal waters. - Pakist. J. scient. ind. Res, 20, 183-187.

Roberson, B. S., 1981. Detection of fish antibody by thin-layer ELISA. - Devs biol. Stand. 49, 113-118.

Roberson, B. S., Wolski, S. \& Hetrick, F. M., 1982. Anti-Vibrio anguillarum antibody among striped bass (Morone saxatilis) following injection with viable bacteria, or ambient exposure to isolated 0 -antigen or environmental vibrios. - Abstracts of the Annual Meeting of the American Society for Microbiology 82,33 (B91).

Roberts, R. J. (Ed.) 1 1982. Microbial diseases of fish. Acad. Press, New York, 305 pp.

Robohm, R. A., Brown, C. \& Murchelano, R. A., 1979. Comparison of antibodies in marine fish from clean and polluted waters of the New York Bight: Relative levels against 36 bacteria. - Appl. environ. Microbiol. 38, 248-257.

Rodsaether, M. C., Olafsen, J., Rea, J., Myhre, K. \& Steen, J. B., 1977. Copper as an initiating factor of vibriosis (Vibrio anguillarum) in eel (Anguilla anguilla). - J. Fish Biol. 10, 17-21.

Ruby, E. G., Greenberg, E. P. \& Hastings, J. W., 1980. Planktonic marine luminous bacteria: species distribution in the water column. - Appl. environ. Microbiol. 39, 302-306.

Sakazaki, R., Iwanami, S. \& Fukumi, H., 1963. Studies on the enteropathogenic facultatively halophilic bacteria, Vibrio parahaemolyticus. - Jap. J. med. Sci. Biol. 16, 161-168.

Sako, H. \& Kusuda, R., 1978. Chemotherapeutical studies on trimethoprim against vibriosis of pond cultured ayu. Part 1. Microbiological evaluation of trimethoprim and sulfonamides on the causative agent, Vibrio anguillarum. - Fish Pathol. 13, 91-96.

Sako, $H_{*}$ Kusuda, R. \& Tabata, T., 1979. Chemotherapeutical studies on trimethoprim against 
vibriosis of pond cultured ayu (Plecoglossus altivelis). 2. Tissue levels after administration of trimethoprim-sulfadoxine mixture. - Fish Pathol. 14, 65-70.

Sawyer, E. S. \& Strout, R. G., 1977. Survival and growth of vaccinated, medicated and untreated coho salmon (Oncorhynchus kisutch) exposed to Vibrio anguillarum. - Aquaculture 10, 311-315.

Sawyer, E. S., Strout, R. G. \& Coutermarsh, B. A., 1979. Comparative susceptibility of Atlantic (Salmo salar) and coho (Oncorhynchus kisutch) salmon to 3 strains of Vibrio anguillarum from the Maine-New Hampshire coast. - J. Fish. Res. Bd Can. 36, 280-282.

Schmidt, U., Chmel, H. \& Cobbs, C., 1979. Vibrio alginolyticus infections in humans. - J. clin. Microbiol. 10, 666-668.

Schiewe, M. H., 1983. Vibrio ordalii as a cause of vibriosis in salmonid fish. In: Bacterial and viral diseases of fish, molecular studies. Ed. by J. H. Crosa. Univ. of Washington, Seattle, 31-40.

Schiewe, M. H. \& Crosa, J. H., 1981. Molecular characterization of Vibrio anguillarum biotype 2. Can. J. Microbiol. 27, 1011-1018.

Schiewe, M. H., Trust, T. J. \& Crosa, J. H., 1981. Vibrio ordalii sp. nov.: a causative agent of vibriosis in fish. - Curr. Microbiol. 6, 343-348.

Sindermann, C. J., 1970. Principal diseases of marine fish and shellfish. Acad. Press, New York, $369 \mathrm{pp}$.

Singleton, F. L., Attwell, R., Jangi, S. \& Colwell, R. R., 1982. Effects of temperature and salinity on Vibrio cholerae growth. - Appl. environ. Microbiol. 44, 1047-1058.

Smith, G. C. \& Merkel, J. R., 1982. Collagenolytic activity of Vibrio vulnificus: Potential contribution to its invasiveness. - Infect. Immun. 35, 1155-1156.

Snieszko, S. F. \& Friddle, S. B., 1949. Prophylaxis of furunculosis in brook trout (Salvelinus fontinalis) by oral immunization and sulfamerazine. - Progve Fish Cult. 11, 161-168.

Snieszko, S. F., Griffin, P. J. \& Friddle, S. B., 1952. Antibiotic treatment of ulcer disease and furunculosis in trout. - Trans. N. Am. Wildl. Conf. 17, 197-213.

Strusiewicz, B. \& Serban, D., 1980. The enterotoxicity of nonagglutinating vibrios. - Rev. Ig. Bacteriol. Virusol. Parazitol. Epidemiol. Pneumoftiziol. (Ser. Bacteriol. Virusol. Parazitol. Epidermiol.) 28, 215-218.

Strusiewicz, B., Cvasniuc, D., Florian, V., Cvasniuc, T. \& Busca, M., 1980. Nonagglutinating vibrios, etiologic agents of diarrheic disease: Their presence and dissemination in the external environment. - Rev. Ig. Bacteriol. Virusol. Parazitol. Epidemiol. Pneumoftiziol. (Ser. Ig.) 29, 135-140.

Szeness, L., Sey, L. \& Szeness, A., 1979. Bacteriological studies of the intestinal content of aquatic birds, fishes, and frogs with special reference to the presence of noncholera vibrios. $-\mathrm{Zbl}$. Bakt. ParasitKde Infektionskr. Hyg. (Abt. 1, Orig., R. A.: Med. Mikrobiol. Parasitol.) 245, 89-95.

Tajima, K., Yoshimizu, M., Ezura, Y. \& Kimura, T., 1981. Causative organisms of vibriosis among pen cultured coho salmon (Oncorhynchus kisutch) in Japan. - Bull. Jap. Soc. scient. Fish. 47, $35-42$.

Takeji, S., Susumu, I., Shiteru, M. \& Akira, G., 1981. Immersion and oral bacterins used in combination to immunize ayu (Plecoglossus altivelis) against vibriosis. - Devs biol. Stand. 49 , $461-462$.

Tashiro, F., Morikawa, S., Motonishi, A., Sanjo, I., Kimura, N., Inoue, K., Nomura, T., Ushiyama, M. \& Jo, Y., 1979. Chemotherapy of fish diseases with piromidic acid. 2. Its clinical studies against bacterial infections in cultured salmonids and eels (Anguilla japonica). - Fish Pathol. 14, 93-101.

Tison, D. L., Nishibuchi, M., Greenwood, J. D. \& Seidler, R. J., 1982. Vibrio vulnificus biogroup 2: new biogroup pathogenic for eels. - Appl. environ. Microbiol. 44, 640-646.

Toranzo, A. E., Barja, J. L., Colwell, R. R. \& Hetrick, F. M., 1983a. Characterization of plasmids in bacterial fish pathogens. - Infect. Immun. 39, 184-192.

Toranzo, A. E., Barja, J. L., Potter, S, A., Colwell, R. R., Hetrick, F. M. \& Crosa, J. H., 1983b. Molecular factors associated with virulence of marine vibrios isolated from striped bass in Chesapeake Bay. - Infect. Immun. 39, 1220-1227.

Toranzo, A. E., Barja, J. L., Colwell, R. R., Hetrick, F. M. \& Crosa, J. H., 1983c. Hemagglutinating, haemolytic and cytotoxic activities of Vibrio anguillarum and related vibrios isolated from striped bass on the Atlantic Coast. - FEMS Microbiol. Lett. 18, 257-262.

Trust, T. J., Courtice, I. D., Khouri, A. G., Crosa, J. H. \& Schiewe, M. H., 1981. Serum resistence and hemagglutination ability of marine vibrios pathogenic for fish. - Infect. Immun. 34, 702-707. 
Watkins, W. D., Wolke, R. E. \& Cabelli, V. J., 1981. Pathogenicity of Vibrio anguillarum for juvenile winter flounder, Pseudopleuronectes americanus. - Can. J. Fish. aquat. Sci. 38, 1045-1051.

West, P. A. \& Colwell, R. R., 1984. Identification and classification of Vibrionaceae - an overview. In: Vibrios in the environment. Ed. by R. R. Colwell. Wiley, New York, 285-363.

Williams, S. F. \& Caldwell, R. S., 1978. Growth, food conversion, and survival of 0 group English sole (Parophrys vetulus) at 5 temperatures and 5 rations. - Aquaculture 15, 129-140.

Xu, H.-S., Roberts, N., Singleton, F. L., Attwell, R. W., Grimes, D. J. \& Colwell, R. R., 1982. Survival and viability of nonculturable Escherichia coli and Vibrio cholerae in the estuarine and marine environment. - Microb. Ecol. 8, 313-323.

Yamanoi, H., Muroga, K. \& Takahashi, S., 1980. Physiological characteristics and pathogenicity of NAG vibrio isolated from diseased ayu. - Fish Pathol. 15, 69-73.

Yasunaga, N. \& Yamamoto, N., 1977. Characteristics of bacterial strains isolated from so-called vibriosis of cultured red sea-bream in the winter of 1977. - Fish Pathol. 12, 209-214.

Yetinson, T. \& Shilo, M., 1979. Seasonal and geographic distribution of luminous bacteria in the eastern Mediterranean Sea and the Gulf of Elat. - Appl. environ. Microbiol. 37, 1230-1238.

Yoshimizu, M., Kimura, T. \& Sakai, M., 1976a. Studies on the intestinal microflora of salmonids. Part 2. Effects of artificial transplanting from fresh water into sea water on the intestinal microflora of feeding and nonfeeding fish. - Bull. Jap. Soc. scient. Fish. 42, 863-873.

Yoshimizu, M., Kimura, T. \& Sakai, M., 1976b. Studies on the intestinal microflora of salmonids. Part 3. The intestinal microflora of salmon living in the open sea. - Bull. Jap. Soc. scient. Fish. $42,875-884$.

Yoshimizu, M., Kimura, T. \& Sakai, M., 1976c. Studies on the intestinal microflora of salmonids. Part 5. The intestinal microflora of the anadromous salmon. - Bull. Jap. Soc. scient. Fish. 42, 1291-1298. 